\title{
Nonlinear Partial Differential Equations Model Related to Oxidation Pond Treatment System: A Case Study of mPHO at Taman Timor Oxidation Pond, Johor Bahru
}

\author{
${ }^{1}$ Amir S. A. Hamzah*, ${ }^{2,3}$ Ali H. M. Murid \\ ${ }^{1}$ Department of Fundamental and Applied Sciences, \\ Faculty of Science and Information Technology, \\ Universiti Teknologi PETRONAS, 36210 Bandar Seri Iskandar, Perak, Malaysia \\ ${ }^{2}$ Department of Mathematical Sciences, Faculty of Science, \\ Universiti Teknologi Malaysia, 81310 UTM Johor Bahru, Johor, Malaysia \\ ${ }^{3}$ UTM Centre for Industrial and Applied Mathematics (UTM-CIAM), \\ Ibnu Sina Institute for Scientific and Industrial Research (ISI-SIR), \\ Universiti Teknologi Malaysia, 81310 UTM Johor Bahru, Johor, Malaysia \\ *Corresponding author: syafiq.hamzah@utp.edu.my
}

Article history

Received: 22 November 2017

Received in revised form: No revision

Accepted: 27 December 2017

Published on line: 1 December 2018

\begin{abstract}
This study presents a mathematical model examining wastewater pollutant removal through an oxidation pond treatment system. This model was developed to describe the reaction between microbe-based product $\mathrm{mPHO}$ (comprising Phototrophic bacteria (PSB)), dissolved oxygen (DO) and pollutant namely chemical oxygen demand (COD). It consists of coupled advection-diffusion-reaction equations for the microorganism (PSB), DO and pollutant (COD) concentrations, respectively. The coupling of these equations occurred due to the reactions between PSB, DO and COD to produce harmless compounds. Since the model is nonlinear partial differential equations (PDEs), coupled, and dynamic, computational algorithm with a specific numerical method, which is implicit Crank-Nicolson method, was employed to simulate the dynamical behaviour of the system. Furthermore, numerical results revealed that the proposed model demonstrated high accuracy when compared to the experimental data.
\end{abstract}

Keywords Oxidation pond; nonlinear PDEs; PSB; implicit Crank-Nicolson.

Mathematics Subject Classification 35B65, 65N99, 92B05.

\section{Introduction}

Oxidation pond technique has been acknowledged as the most popular approach among small communities due to its low construction and operating costs [1]. The construction and maintenance costs of this treatment are inexpensive compared to other recognized treatment systems 
including microbial fuel cell (MFC), membrane bioreactor (MBR), and rotating biological contactor $(\mathrm{RBC})$. The core procedure of an oxidation pond treatment process is the degradation of contaminants and organic matter in two conditions; where oxygen is present (aerobic) or absence (anaerobic). At each stage, existing microorganisms are used to breakdown either organic or inorganic substances of influent and to reduce organic material into more concise forms, which are carbon dioxide, water, and cell biomass.

Oxidation pond chosen for the pilot scale study is an exposed oxidation pond located at Taman Timor Oxidation Pond, Tampoi, Johor, as it has been experimentally studied by JBiotech for three months period to observe the effects of microbe-based product (mPHO) in treating sewage. Nonetheless, there is no specific study done on this product until now. Briefly, the size of this pond is estimated about 1,909 square metres with a depth of 1.5 metres and total water volume of 2,864.13 cubic metres or 2,864,125.13 litres (refer to Figure 2 and Figure $3)$. However, the input and output flow rate of wastewater as well as the volume of rain may not change the volume of water in the pond as the wastewater is discharged due to overflow. In order to intensify the effectiveness of oxidation pond technique and to accelerate the population of Phototrophic bacteria (PSB) in the pond, mPHO containing mainly PSB have been added regularly within three months period of study between 13 November 2013 to 12 February 2014.

The product mPHO is made from selected species of PSB (refer Figure 4) manufactured by J-Biotech. About 1,375 litres of mPHO were applied to the pond throughout three months of treatment. Samples were collected at two points, which are CP1 (influent and application of mPHO) and CP2 (effluent) (refer to Figure 5). Comparison of data taken at both points $\mathrm{CP} 1$ and $\mathrm{CP} 2$ demonstrated that $\mathrm{mPHO}$ has a good effect in reducing the concentration of pathogenic bacteria (E. coli and Coliform), BOD, COD and other pollutants as the PSB and dissolved oxygen (DO) concentration increases.

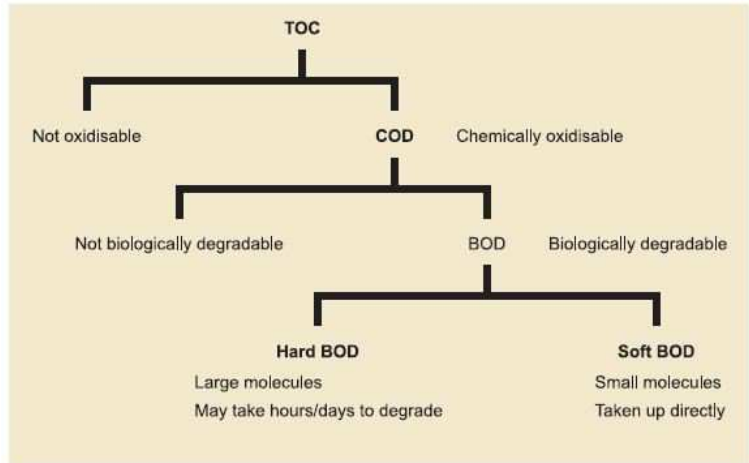

Figure 1: Relationship Between the Organic Carbon in Sewage [2]

\section{$2 \quad$ Literature Review}

There are several types of mathematical modelling that are widely used in wastewater treatment process. Some examples of mathematical models related to rivers and ponds are also stated in the sections below. Findings from this study demonstrated that these models were further improved using the advancement in computing by considering the dynamical structure of biological system. 


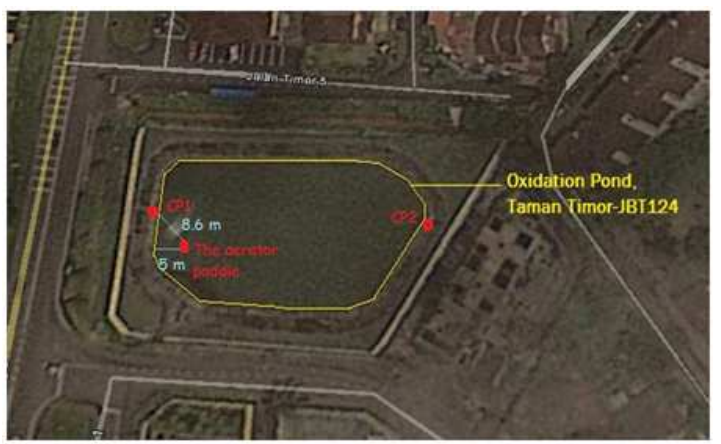

Figure 2: Aerial View of Taman Timor Oxidation Pond, Johor Bahru [3]

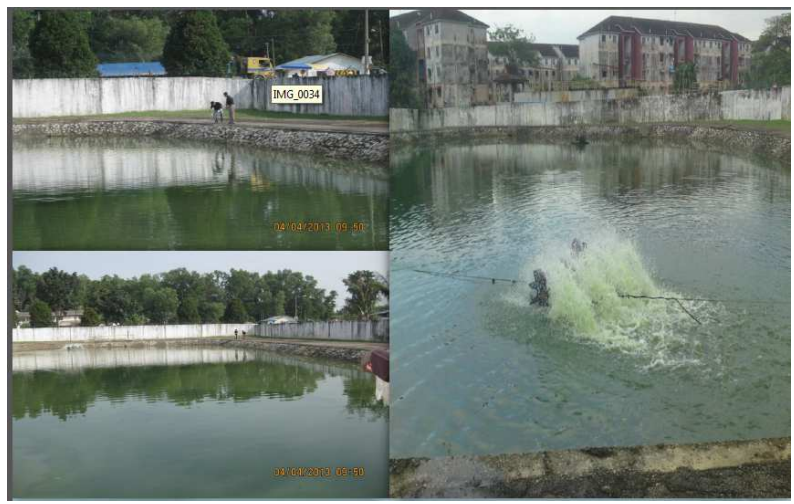

Figure 3: Physical Condition of Taman Timor Oxidation Pond, Johor Bahru [3]

Wastewater treatment process models consider various types of wastewater problem and select proper modes of treatment as well as the design of the equipment required. Furthermore, the theories involved in the specific process such as chemical kinetics, material and energy balances are discussed. Wastewater process models can be successfully used in planning and developing several applications such as river, pond and wetland.

Mathematical modelling in solving actual problems such as water pollution has been developed since 1925 by Streeter and Phelps [4]. One of the issues of concern is to scrutinize the quality of water accessible in rivers and stabilization ponds. One of the earliest mathematical modelling of water quality given in Beck and Young [4] by using Streeter-Phelps Equation to study the relationship between BOD and DO on the River Cam, Eastern England. The model used a linear first order differential equation as

$$
\frac{d D}{d t}=k_{1} L_{t}-k_{2} D
$$

where $D$ is the saturation oxygen deficit, which can be derived from the dissolved oxygen concentration at saturation minus the actual dissolved oxygen concentration $\left(\mathrm{g} \mathrm{m}^{-3}\right), k_{1}$ is the deoxygenation rate $\left(\right.$ day $\left.^{-1}\right), k_{2}$ is the reaeration rate $\left(\right.$ day $\left.^{-1}\right), L_{t}$ is the oxygen demand remaining at time $t$, and $t$ is the elapsed time, usually in day.

This model explains how BOD and DO can vary along with observing period. Many studies have been conducted to predict the effluent quality of river and stabilization ponds. The 


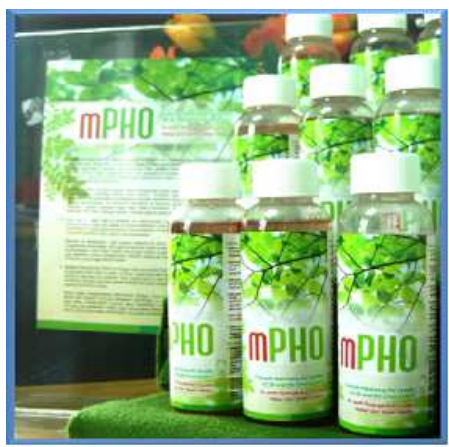

Figure 4: Beneficial Microbe-based Product (mPHO) Produced by J-Biotech company [3]

(a)
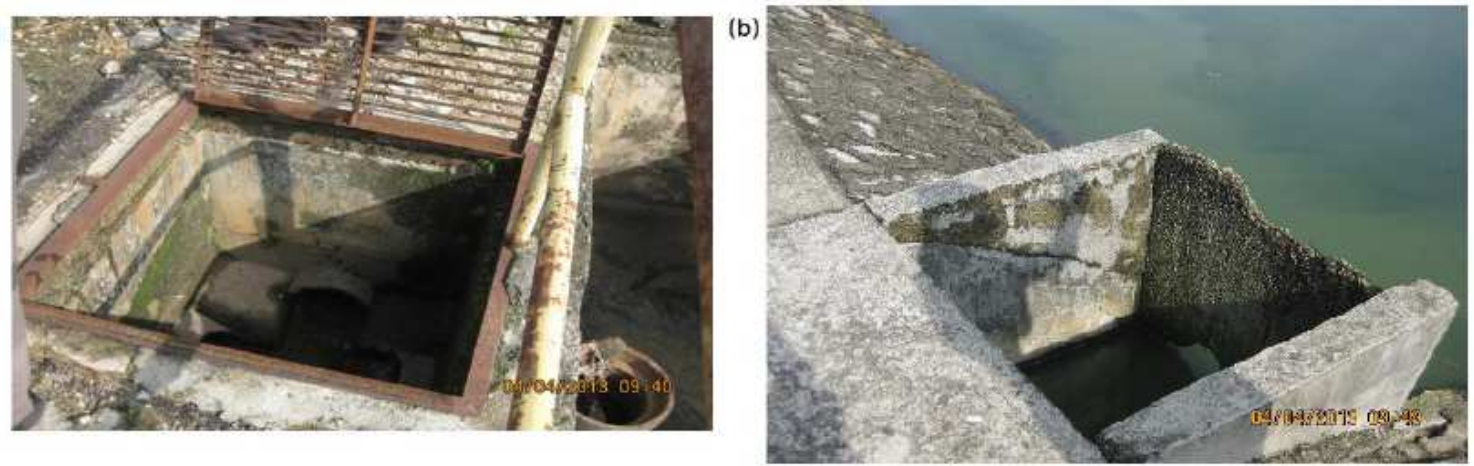

Figure 5: (a) Location of CP1 (Influent) (b) Location of CP2 (Effluent) [3]

Streeter-Phelps equation has been frequently used as a reference, while ordinary differential equations were used as the basis in relating parameters to each other. Through this model, significant relationship between parameters involved in the ecosystem is obtained. For instance, the pollutant against DO, algae against DO, and bacteria against algae.

There are also other mathematical models developed for specific problems that occur in a given locality. A study has been conducted on Tha Chin river stream in Thailand considering the effects of pollutant with dissolved oxygen [5]. This study proposed the model of twodimensional coupled advection-dispersion equations for both state variables, respectively. The relationship between state variables was used considering that the interactions occurred between materials contaminated with oxygen will produce harmful substances. In this model, pollutant and DO concentrations were permitted to fluctuate along the length of stream and dealt as homogeneous over the cross-segment of river subject to Dobbin's criterion [6]. For simplification, the model was reduced to steady state solutions and analytically solved for simple cases.

Besides, there is another study developing mathematical model to predict the specific growth rate and biomass concentration of microbes in wastewater treatment [7]. This study suggests that the rate of bacterial growth can be defined as first order reaction

$$
r_{g}=\frac{\mu_{m} S}{K_{s}+S}
$$

where $r_{g}$ is the rate of bacterial growth $\left(\right.$ time $\left.^{-1}\right), \mu_{m}$ is the maximum specific growth rate 
$\left(\right.$ time $\left.^{-1}\right), S$ is concentration of growth limiting substrate in the effluent (mass (unit volume) $)^{-1}$ time $^{-1}$ ), $K_{s}$ is the half velocity constant (mass (unit volume) ${ }^{-1}$ time $^{-1}$ ). This finding presents Michaelis-Menten term in the hypothesis of growth model with the view that the growth rate of enzyme will take the same form. In biochemistry, Michaelis-Menten term expression can be considered as among the best-known models for enzyme kinetics. This model is associated with German biochemist Leonor Michaelis and Canadian physician Maud Menten. The model describes the rate of enzymatic reactions by relating the reaction rate $v$ with substrate $S$ using the formula of

$$
v=\frac{V_{\max }[S]}{K_{m}+[S]},
$$

where $V_{\max }$ is the maximum rate attained by the system referred to as saturating substrate concentrations (refer Figure 6). Meanwhile, the Michaelis constant $K_{m}$ is the substrate concentration that takes half the value of $V_{\max }$.

Apart from that, an ecological study has been conducted proposing a mathematical model to obtain input/output relationships between upstream and downstream of a river for DO and BOD parameters [8]. The appropriate example is the Beck modified Khanna Bhutiani (BMKB) model, which is developed to study the coexisting interaction occurs between DO and BOD. The study of wastewater took place at river Suswa, India. Precisely, the following model

$$
\left\{\begin{array}{l}
\lambda_{1}(S)=C_{1} \lambda_{1}(S-1)+C_{2} U_{1}(S-1)+C_{3} e_{1}(S), \\
\lambda_{2}(S)=C_{4} \lambda_{1}(S-1)+C_{5} U_{1}(S-1)-C_{6} e_{1}(S),
\end{array}\right.
$$

was used where $\lambda_{1}(S)$ is the value of DO $(\mathrm{mg} / \mathrm{l})$ to be obtained in particular season, $\lambda_{2}(S)$ is the value of BOD $(\mathrm{mg} / \mathrm{l}), \lambda_{1}(S-1)$ is DO/BOD observation of same place in previous season, $U_{1}(S-1)$ is DO/BOD observation of upstream in previous season, $e_{1}(S)$ is the error of possibility while constants $\left(c_{1}, c_{2}, \ldots, c_{6}\right)$ are described as the specific rates of the aforementioned term. The results were achieved by computing DO divided by BOD of the same upstream in the past season, which remains a single output solution. The model has been proved by the water quality information of the samples gathered from river Suswa in various seasons.

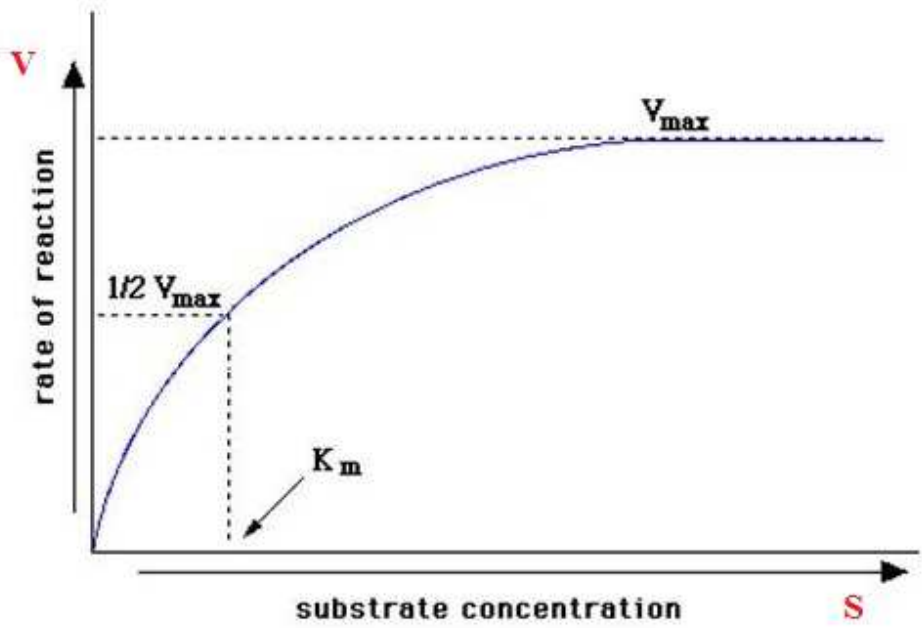

Figure 6: Michaelis-Manten Kinetics [12] 
A more complex model has been considered discussing on the variations of COD, DO, ammonia, phosphorus, bacteria and algae concentrations with time and the dimensions of the pond [9-11]. This model predicts the correlation between those aforementioned variables at the effluent to measure the quality of the stabilization pond (natural pond). A two-dimensional hydraulic model was employed taking into consideration the dispersed flow and diffusion in horizontal and vertical directions, respectively. The pilot scale study of this model focused around the accumulated data from a full-scale lake in Turkey. The model can be utilized to redesign new outline for the lakes, thus enhancing the pro-fluent nature of the existing lakes.

Meanwhile, for this study, the advection-diffusion-reaction equation model proposed by Pimpunchat et al. [5] was extended to three state variables in this study, which are phototrophic bacteria (PSB), chemical oxygen demand (COD) and DO. Currently, there are several mathematical models available for simulating oxidation pond process where some important parameters are considered such as bacteria (cleansing agent), pollutants and dissolved oxygen (DO). However, previous results did not provide a good approximation on the required parameters.

\section{Application of mPHO at Taman Timor Oxidation Pond}

This section presents the application of mPHO product by J-Biotech Company at Taman Timor oxidation pond, Skudai, Johor. The treatment was conducted within three months period from 14 November 2014 to 13 February 2015 [3]. The location for applying mPHO and sampling points are presented in Figure 3.4. In the first week, 25 litres $\mathrm{mPHO}$ was applied each day with 2 days break in the weekend followed by adding 30 litres $\mathrm{mPHO}$ each day for the second week. This phase is considered as the first phase of application. During the third until twelve-th week, 10 litres of $\mathrm{mPHO}$ was applied each day with 2 days break in the weekend (refer to Table 1 and Table 2). Phase 1 and Phase 2 represented a continuous treatment of $\mathrm{mPHO}$ application within 91 days. All the amounts of $\mathrm{mPHO}$ given during the study were applied by the company using trial and error method. Meanwhile, the two days break during the weekend is considered as the regular holiday period. Hence, mathematical modelling was utilised in this study to assist in explaining further treatment process and aid in managing a more efficient treatment process.

\section{Advection-Diffusion-Reaction Equation Model (Transport of Pollutant)}

To represent the oxidation pond treatment system, the PDEs model was used considering the dimensions of the pond $(x)$ as well as time observed $(t)$. Therefore, the length of pond associated with variables $x$ must be included as the independent variables for the model. This model has to be considered by two independent variables, which are $x$ and $t$. This will allow the wastewater flows through the pond that contains several substances to be described by both advection and diffusion terms. Advection is the transport of substances through fluid. Mathematically, it can be written as the partial differential equation that governs the motion of a conserved scalar field as it is advected by a known velocity vector field [13]. One example of visualized phenomenon is the transport of crude oil dumped into a river. As the river flows, crude oil will move downstream in an oscillating behaviour via advection where the water's movement transports the oil. Meanwhile, the diffusion term is known as the second order 
Table 1: Treatment Schedule for mPHO Application at Taman Timor Oxidation Pond (Phase 1) [3]

\begin{tabular}{|c|c|c|c|c|}
\hline \multicolumn{3}{|c|}{ Application / Activities } & Frequency & Location \\
\hline \multicolumn{3}{|c|}{ Pre-Sampling } & 3 times & Both Point ( CP 1 \& CP 2) \\
\hline $\begin{array}{l}\text { Treatment } \\
\text { Approaches }\end{array}$ & Day (Date) & $\begin{array}{l}\text { Application } \\
\text { / Activities }\end{array}$ & $\begin{array}{l}\text { Quantity } \\
\text { /Frequency }\end{array}$ & Location \\
\hline \multirow[t]{15}{*}{$\begin{array}{l}\text { Intensive } \\
(\text { Phase } 1) \\
\end{array}$} & $1(14 / 11 / 2013)$ & Sampling & 2 locations & Both Point ( CP $1 \&$ CP 2) \\
\hline & & $\mathrm{mPHO}$ & 25 liters & CP 1 (Influent) \\
\hline & $2(15 / 11 / 2013)$ & $\mathrm{mPHO}$ & 25 liters & CP 1 (Influent) \\
\hline & $3(16 / 11 / 2013)$ & $\mathrm{mPHO}$ & 25 liters & CP 1 (Influent) \\
\hline & $4(17 / 11 / 2013)$ & Sampling & 2 locations & Both Point ( CP 1 \& CP 2) \\
\hline & & $\mathrm{mPHO}$ & 25 liters & CP 1 (Influent) \\
\hline & $5(18 / 11 / 2013)$ & $\mathrm{mPHO}$ & 25 liters & CP 1 (Influent) \\
\hline & \multicolumn{4}{|c|}{$(19-20 / 11 / 2013)$ Break for 2 days } \\
\hline & $8(21 / 11 / 2013)$ & Sampling & 2 locations & Both Point ( CP 1 \& CP 2) \\
\hline & & $\mathrm{mPHO}$ & 30 litres & CP 1 (Influent) \\
\hline & $9(22 / 11 / 2013)$ & $\mathrm{mPHO}$ & 30 litres & CP 1 (Influent) \\
\hline & $10(23 / 11 / 2013)$ & $\mathrm{mPHO}$ & 30 litres & CP 1 (Influent) \\
\hline & $11(24 / 11 / 2013)$ & Sampling & 2 locations & Both Point ( CP $1 \&$ CP 2) \\
\hline & & $\mathrm{mPHO}$ & 30 litres & CP 1 (Influent) \\
\hline & $12(25 / 11 / 2013)$ & $\mathrm{mPHO}$ & 30 litres & CP 1 (Influent) \\
\hline
\end{tabular}

PDEs. Cross sectional area $(A)$ of a pond is also considered as one of the important factors for this model. Additionally, this factor has been previously employed by Pimpunchat [5] for a system of PDEs comprising DO and pollutants. This extended model is made to introduce another state variable which is PSB as the cleansing agent used in the process of degrading pollutants. Variables and parameters used in this mathematical model are stated in Table 4.14 and Table 4.15. Table 4.16 demonstrates the equation of all process rates considered in the Mathematical Model.

Meanwhile, the unknown constants of the model which is stated in Table 4.15 can also be determined using the parameter estimation (least squares) method in Mathematica routine NonlinearModelFit based on the experimental data at CP2. Hence, a system consists of three second order PDEs with coupled-equation for the aforementioned state variables is constructed and listed in equations (4-6). 
Table 2: Treatment Schedule for mPHO Application at Taman Timor Oxidation Pond (Phase 2) [3]

\begin{tabular}{|c|c|c|c|c|}
\hline $\begin{array}{l}\text { Treatment } \\
\text { Approaches }\end{array}$ & $\begin{array}{l}\text { Cycles } \\
\text { (week) }\end{array}$ & $\begin{array}{c}\text { Application / } \\
\text { Activities }\end{array}$ & $\begin{array}{c}\text { Quantity } \\
\text { (Litre) }\end{array}$ & Location \\
\hline & & Sampling & 1 & CP $1 \&$ CP 2 \\
\hline \multirow[t]{7}{*}{$\begin{array}{l}\text { Continuous } \\
\text { (Phase 2) }\end{array}$} & $\begin{array}{l}1^{\text {st }} \\
(28 / 11 / 2013- \\
4 / 12 / 2013)\end{array}$ & Application $\mathrm{mPHO}$ & 100 & CP 1 (Influent) \\
\hline & $\begin{array}{l}2^{\text {nd }} \\
(5 / 12 / 2013- \\
11 / 12 / 2013)\end{array}$ & Application $\mathrm{mPHO}$ & 100 & CP 1 (Influent) \\
\hline & $\begin{array}{l}3^{\text {rd }} \\
(12 / 12 / 2013- \\
18 / 12 / 2013)\end{array}$ & Application mPHO & 100 & CP 1 (Influent) \\
\hline & $\begin{array}{l}4^{\text {th }} \\
(19 / 12 / 2013- \\
25 / 12 / 2013)\end{array}$ & Application $\mathrm{mPHO}$ & 100 & CP 1 (Influent) \\
\hline & $\begin{array}{l}5^{\text {th }} \\
(2 / 1 / 2014- \\
8 / 1 / 2014)\end{array}$ & Application $\mathrm{mPHO}$ & 100 & CP 1 (Influent) \\
\hline & $\begin{array}{l}7^{\text {th }} \\
(9 / 1 / 2014- \\
15 / 1 / 2014)\end{array}$ & Application mPHO & 100 & CP 1 (Influent) \\
\hline & $\begin{array}{l}8^{\text {th }} \\
(16 / 1 / 2014- \\
22 / 1 / 2014)\end{array}$ & Application mPHO & 100 & CP 1 (Influent) \\
\hline
\end{tabular}

$$
\begin{gathered}
\frac{\partial(A M(x, t))}{\partial t}=D_{M} \frac{\partial^{2}(A M(x, t))}{\partial x^{2}}-v \frac{\partial(A M(x, t))}{\partial x}+ \\
c_{1} \frac{P(x, t)}{k_{P}+P(x, t)} A X(x, t) M(x, t)+\mu_{b} M(x, t)\left(1-\frac{M(x, t)}{k_{m}}\right) \\
\frac{\partial(A P(x, t))}{\partial t}=D_{P} \frac{\partial^{2}(A P(x, t))}{\partial x^{2}}-v \frac{\partial(A P(x, t))}{\partial x}-c_{1} \frac{P(x, t)}{k_{P}+P(x, t)} A X(x, t) M(x, t), \\
\frac{\partial(A X(x, t))}{\partial t}=D_{X} \frac{\partial^{2}(A X(x, t))}{\partial x^{2}}-v \frac{\partial(A X(x, t))}{\partial x}- \\
c_{1} \frac{P(x, t)}{k_{P}+P(x, t)} A X(x, t) M(x, t)+k_{L}(\alpha-X(x, t)),
\end{gathered}
$$


Table 3: Description of State Variables Used in the Mathematical Model

\begin{tabular}{|c|l|l|}
\hline Symbol & \multicolumn{1}{|c|}{ Description } & Unit \\
\hline$M(x, t)$ & $\begin{array}{l}\text { Concentration of PSB in the pond where } x \text { varies from 0 to } \\
54 \text { metres and } t \text { varies from initial time up to 91 days }\end{array}$ & $\mathrm{g} \mathrm{m}^{-3}$ \\
\hline$P(x, t)$ & Concentration of COD in the pond & $\mathrm{g} \mathrm{m}^{-3}$ \\
\hline$X(x, t)$ & Concentration of DO in the pond & $\mathrm{g} \mathrm{m}^{-3}$ \\
\hline$U(t)$ & Amount of mPHO applied to the pond according to schedule & $\mathrm{m}^{3} \mathrm{day}^{-1}$ \\
\hline$M_{i}(t)$ & Input of PSB from the inlet source that varies with time & $\mathrm{g} \mathrm{m}^{-3}$ \\
\hline$P_{i}(t)$ & Input of COD from the inlet source that varies with time & $\mathrm{g} \mathrm{m}^{-3}$ \\
\hline$X_{i}(t)$ & Input of DO from the inlet source that varies with time & $\mathrm{g} \mathrm{m}^{-3}$ \\
\hline
\end{tabular}

Table 4: Process Rates

\begin{tabular}{|c|l|l|l|}
\hline Symbol & \multicolumn{1}{|c|}{ Description } & \multicolumn{1}{|c|}{ Formula } & Unit \\
\hline $\mathrm{B}$ & $\begin{array}{l}\text { Breakdown of organic/ } \\
\text { inorganic matter }\end{array}$ & $k_{1} \frac{P(x, t)}{k_{P}+P(x, t)} A X(x, t) B(x, t)$ & $\mathrm{g} \mathrm{m}^{-3}$ \\
\hline $\mathrm{F}$ & Mass transfer of oxygen & $k_{L}(\alpha-X(x, t))$ & $\mathrm{g} \mathrm{m}^{-3}$ \\
\hline $\mathrm{L}$ & $\begin{array}{l}\text { Logistic growth of } \\
\text { bacteria }\end{array}$ & $\mu_{b} M(x, t)\left(1-\frac{M(x, t)}{k_{m}}\right)$ & $\mathrm{g} \mathrm{m}^{-3}$ \\
\hline
\end{tabular}

where $0 \leq t \leq 90$ day, $0 \leq x \leq 54$ meter. At initial time and length of $t=0$, and $x=0$, the value of PSB is $0.00036 \mathrm{~g} \mathrm{~m}^{-3}$ with $116.7 \mathrm{~g} \mathrm{~m}^{-3} \mathrm{COD}$ and $2.764 \mathrm{~g} \mathrm{~m}^{-3} \mathrm{DO}$. The initial conditions presented below were obtained by quadratic interpolation of the data at CP1 and CP2 when $t=0$.

Initial Conditions:

$$
\left\{\begin{aligned}
M(x, 0) & =\frac{1}{54^{2}}(0.001-0.00036) x^{2}+0.00036 \\
P(x, 0) & =\frac{1}{54^{2}}(65-116.7) x^{2}+116.7 \\
X(x, 0) & =\frac{1}{54^{2}}(2.8185-2.764) x^{2}+2.764
\end{aligned}\right.
$$

Boundary Conditions:

$$
\left\{\begin{array}{lcc}
\left.\frac{\partial M(x, t)}{\partial x}\right|_{x=0}=0 ; & \left.\frac{\partial P(x, t)}{\partial x}\right|_{x=0}=0 ; & \left.\frac{\partial X(x, t)}{\partial x}\right|_{x=0}=0 \\
M(0, t)=M_{i}(t) ; & P(0, t)=P_{i}(t) ; & X(0, t)=X_{i}(t) .
\end{array}\right.
$$


Table 5: Parameter Values Used in the Mathematical Model

\begin{tabular}{|c|c|c|c|c|}
\hline Symbol & Description & Value & Unit & Source \\
\hline$m_{0}$ & $\begin{array}{l}\text { Rate of PSB addition within the } \\
\text { pond }\end{array}$ & 19.1 & $\mathrm{~g} \mathrm{~m}^{-3}$ & $\begin{array}{l}\text { MISG } 2014 \\
\text { Report [3] }\end{array}$ \\
\hline$p_{0}$ & $\begin{array}{l}\text { Concentration of COD in one } \mathrm{m}^{3} \text { of } \\
\text { sewage from input } \mathrm{CP} 1\end{array}$ & 50.0 & $\mathrm{~g} \mathrm{~m}^{-3}$ & $\begin{array}{l}\text { MISG } 2014 \\
\text { Report [3] }\end{array}$ \\
\hline$v_{s}$ & $\begin{array}{l}\text { Average amount of sewage from } \\
\text { CP1 }\end{array}$ & 290 & $\mathrm{~m}^{3}$ day $^{-1}$ & $\begin{array}{l}\text { MISG } 2014 \\
\text { Report [3] }\end{array}$ \\
\hline$v_{p}$ & Volume of the pond & 2864 & $\mathrm{~m}^{3}$ & $\begin{array}{l}\text { MISG } 2014 \\
\text { Report [3] }\end{array}$ \\
\hline$v$ & Velocity of wastewater in the pond & 7.54 & $\mathrm{~m} \mathrm{day}^{-1}$ & $\begin{array}{l}\text { MISG } 2014 \\
\text { Report [3] }\end{array}$ \\
\hline$A$ & $\begin{array}{l}\text { Cross section area of oxidation } \\
\text { pond }\end{array}$ & 53 & $\mathrm{~m}^{2}$ & $\begin{array}{l}\text { MISG } 2014 \\
\text { Report [3] }\end{array}$ \\
\hline$\alpha$ & Saturated oxygen concentration & 3.4 & $\mathrm{~g} \mathrm{~m}^{-3}$ & Calibrated \\
\hline$\mu_{b}$ & Maximum growth rate for PSB & 31 & $\mathrm{~m}^{2} \mathrm{day}^{-1}$ & Calibrated \\
\hline$D_{M}$ & $\begin{array}{l}\text { Diffusion coefficient of PSB in the } \\
x \text { direction }\end{array}$ & 50 & $m^{2}$ day $^{-1}$ & Calibrated \\
\hline$D_{P}$ & $\begin{array}{l}\text { Diffusion coefficient of COD in the } \\
x \text { direction }\end{array}$ & 50 & $\mathrm{~m}^{2} \mathrm{day}^{-1}$ & Calibrated \\
\hline$D_{X}$ & $\begin{array}{l}\text { Diffusion coefficient of DO in the } x \\
\text { direction }\end{array}$ & 50 & $\mathrm{~m}^{2}$ day $^{-1}$ & Calibrated \\
\hline$k_{L}$ & $\begin{array}{l}\text { Mass transfer rate for oxygen from } \\
\text { air to water }\end{array}$ & 4 & $m^{2}$ day $^{-1}$ & Calibrated \\
\hline$k_{p}$ & $\begin{array}{l}\text { Half saturation oxygen demand } \\
\text { concentration for COD decay }\end{array}$ & 560 & $\mathrm{~g} \mathrm{~m}^{-3}$ & Calibrated \\
\hline$c_{1}$ & $\begin{array}{l}\text { Degradation rate coefficient for } \\
\text { COD }\end{array}$ & 10 & $m^{3} g^{-1}$ day $^{-1}$ & Calibrated \\
\hline$k_{m}$ & $\begin{array}{l}\text { Half-saturation coefficient } \\
\text { growth of PSB }\end{array}$ & $1.7 \times 10^{-4}$ & $\mathrm{~g} \mathrm{~m}^{-3}$ & Calibrated \\
\hline
\end{tabular}


The boundary conditions $M(0, t), P(0, t)$ and $X(0, t)$ can be calculated through linear interpolation of given data at $\mathrm{CP} 1$ and by considering there is no out flux for all state variables at $\mathrm{CP} 1$, which is at $x=0$ at all time.

By using Crank-Nicolson algorithm as already mentioned earlier, equations (4-6) can be discretized into

$$
\begin{gathered}
\frac{A}{\Delta t}\left(M_{i}^{j+1}-M_{i}^{j}\right)=\frac{D_{M}}{2(\Delta x)^{2}}\left(M_{i+1}^{j}-2 M_{i}^{j}+M_{i-1}^{j}+M_{i+1}^{j+1}-2 M_{i}^{j+1}+M_{i-1}^{j+1}\right) \\
-\frac{v}{4 \Delta x}\left(M_{i+1}^{j}-M_{i-1}^{j}+M_{i+1}^{j+1}-M_{i-1}^{j+1}\right)+c_{1} \frac{P_{i}^{j}}{k_{P}+P_{i}^{j}} A X_{i}^{j} M_{i}^{j}+\mu_{b} M_{i}^{j}\left(1-\frac{M_{i}^{j}}{k_{m}}\right) . \\
\frac{A}{\Delta t}\left(P_{i}^{j+1}-P_{i}^{j}\right)=\frac{D_{P}}{2(\Delta x)^{2}}\left(P_{i+1}^{j}-2 P_{i}^{j}+P_{i-1}^{j}+P_{i+1}^{j+1}-2 P_{i}^{j+1}+P_{i-1}^{j+1}\right) \\
-\frac{v}{4 \Delta x}\left(P_{i+1}^{j}-P_{i-1}^{j}+P_{i+1}^{j+1}-P_{i-1}^{j+1}\right)-c_{1} \frac{P_{i}^{j}}{k_{P}+P_{i}^{j}} A X_{i}^{j} M_{i}^{j} . \\
\frac{A}{\Delta t}\left(X_{i}^{j+1}-X_{i}^{j}\right)=\frac{D_{X}}{2(\Delta x)^{2}}\left(X_{i+1}^{j}-2 X_{i}^{j}+X_{i-1}^{j+1}+X_{i+1}^{j+1}-2 X_{i}^{j+1}+X_{i-1}^{j+1}\right) \\
-\frac{v}{4 \Delta x}\left(X_{i+1}^{j}-X_{i-1}^{j}+X_{i+1}^{j+1}-X_{i-1}^{j+1}\right)-c_{1} \frac{P_{i}^{j}}{k_{P}+P_{i}^{j}} A X_{i}^{j} M_{i}^{j}+k_{L}\left(\alpha-X_{i}^{j}\right) .
\end{gathered}
$$

Equations (9-11) can be rewritten as

$$
\begin{aligned}
-\frac{A}{\Delta t} M_{i}^{j} & -\frac{D_{M}}{2(\Delta x)^{2}}\left(M_{i+1}^{j}-2 M_{i}^{j}+M_{i-1}^{j}\right)+\frac{v}{4 \Delta x}\left(M_{i+1}^{j}-M_{i-1}^{j}\right) \\
& -c_{1} \frac{P_{i}^{j}}{k_{P}+P_{i}^{j}} A X_{i}^{j} M_{i}^{j}+\mu_{b} M_{i}^{j}\left(1-\frac{M_{i}^{j}}{k_{m}}\right) \\
& =-\frac{A}{\Delta t} M_{i}^{j+1}+\frac{D_{M}}{2(\Delta x)^{2}}\left(M_{i+1}^{j+1}-2 M_{i}^{j+1}+M_{i-1}^{j+1}\right)-\frac{v}{4 \Delta x}\left(M_{i+1}^{j+1}-M_{i-1}^{j+1}\right) . \\
& -\frac{A}{\Delta t} P_{i}^{j}-\frac{D_{P}}{2(\Delta x)^{2}}\left(P_{i+1}^{j}-2 P_{i}^{j}+P_{i-1}^{j}\right)+\frac{v}{4 \Delta x}\left(P_{i+1}^{j}-P_{i-1}^{j}\right)+c_{1} \frac{P_{i}^{j}}{k_{P}+P_{i}^{j}} A X_{i}^{j} M_{i}^{j} \\
& =-\frac{A}{\Delta t} P_{i}^{j+1}+\frac{D_{P}}{2(\Delta x)^{2}}\left(P_{i+1}^{j+1}-2 P_{i}^{j+1}+P_{i-1}^{j+1}\right)-\frac{v}{4 \Delta x}\left(P_{i+1}^{j+1}-P_{i-1}^{j+1}\right) . \\
-\frac{D_{X}}{\Delta t} X_{i}^{j} & -\frac{D^{j}}{2(\Delta x)^{2}}\left(X_{i+1}^{j}-2 X_{i}^{j}+X_{i-1}^{j}\right)+\frac{v}{4 \Delta x}\left(X_{i+1}^{j}-X_{i-1}^{j}\right)+c_{1} \frac{P_{i}^{j}}{k_{P}+P_{i}^{j}} A X_{i}^{j} M_{i}^{j} \\
& =-\frac{A}{\Delta t} X_{i}^{j+1}+\frac{D_{X}}{2(\Delta x)^{2}}\left(X_{i+1}^{j+1}-2 X_{i}^{j+1}+X_{i-1}^{j+1}\right)-\frac{v}{4 \Delta x}\left(X_{i+1}^{j+1}-X_{i-1}^{j+1}\right) .
\end{aligned}
$$

Equations (12-14) can be rearranged to follow Crank-Nicolson scheme by

$$
\begin{aligned}
& \left(-\frac{D_{M}}{2(\Delta x)^{2}}-\frac{v}{4 \Delta x}\right) M_{i-1}^{j}+\left(-\frac{A}{\Delta t}+\frac{D_{M}}{(\Delta x)^{2}}-c_{1} \frac{P_{i}^{j}}{k_{P}+P_{i}^{j}} A X_{i}^{j}+\mu_{b}\left(1-\frac{M_{i}^{j}}{k_{m}}\right)\right) M_{i}^{j} \\
& \left(-\frac{D_{M}}{2(\Delta x)^{2}}+\frac{v}{4 \Delta x}\right) M_{i+1}^{j}=\left(\frac{D_{M}}{2(\Delta x)^{2}}+\frac{v}{4 \Delta x}\right) M_{i-1}^{j+1}+\left(-\frac{A}{\Delta t}+\frac{D_{M}}{(\Delta x)^{2}}\right) M_{i}^{j+1} \\
& +\left(\frac{D_{M}}{2(\Delta x)^{2}}-\frac{v}{4 \Delta x}\right) M_{i+1}^{j+1}
\end{aligned}
$$




$$
\begin{aligned}
& \left(-\frac{D_{P}}{2(\Delta x)^{2}}-\frac{v}{4 \Delta x}\right) P_{i-1}^{j}+\left(-\frac{A}{\Delta t}+\frac{D_{P}}{(\Delta x)^{2}}+c_{1} \frac{X_{i}^{j} M_{i}^{j}}{k_{P}+P_{i}^{j}} A\right) P_{i}^{j} \\
& \left(-\frac{D_{P}}{2(\Delta x)^{2}}+\frac{v}{4 \Delta x}\right) P_{i+1}^{j}=\left(\frac{D_{P}}{2(\Delta x)^{2}}+\frac{v}{4 \Delta x}\right) P_{i-1}^{j+1}+\left(-\frac{A}{\Delta t}+\frac{D_{P}}{(\Delta x)^{2}}\right) P_{i}^{j+1} \\
& \quad+\left(\frac{D_{P}}{2(\Delta x)^{2}}-\frac{v}{4 \Delta x}\right) P_{i+1}^{j+1} \\
& \left(-\frac{D_{X}}{2(\Delta x)^{2}}-\frac{v}{4 \Delta x}\right) X_{i-1}^{j}+\left(-\frac{A}{\Delta t}+\frac{D_{X}}{(\Delta x)^{2}}+c_{1} \frac{P_{i}^{j} M_{i}^{j}}{k_{P}+P_{i}^{j}}\right) X_{i}^{j} \\
& \left(-\frac{D_{X}}{2(\Delta x)^{2}}+\frac{v}{4 \Delta x}\right) X_{i+1}^{j}=\left(\frac{D_{X}}{2(\Delta x)^{2}}+\frac{v}{4 \Delta x}\right) X_{i-1}^{j+1}+\left(-\frac{A}{\Delta t}+\frac{D_{X}}{(\Delta x)^{2}}\right) X_{i}^{j+1} \\
& \left(\frac{D_{X}}{2(\Delta x)^{2}}-\frac{v}{4 \Delta x}\right) X_{i+1}^{j+1} .
\end{aligned}
$$

Lastly, equations (15-17) can be written into a linear equation matrix system as follows

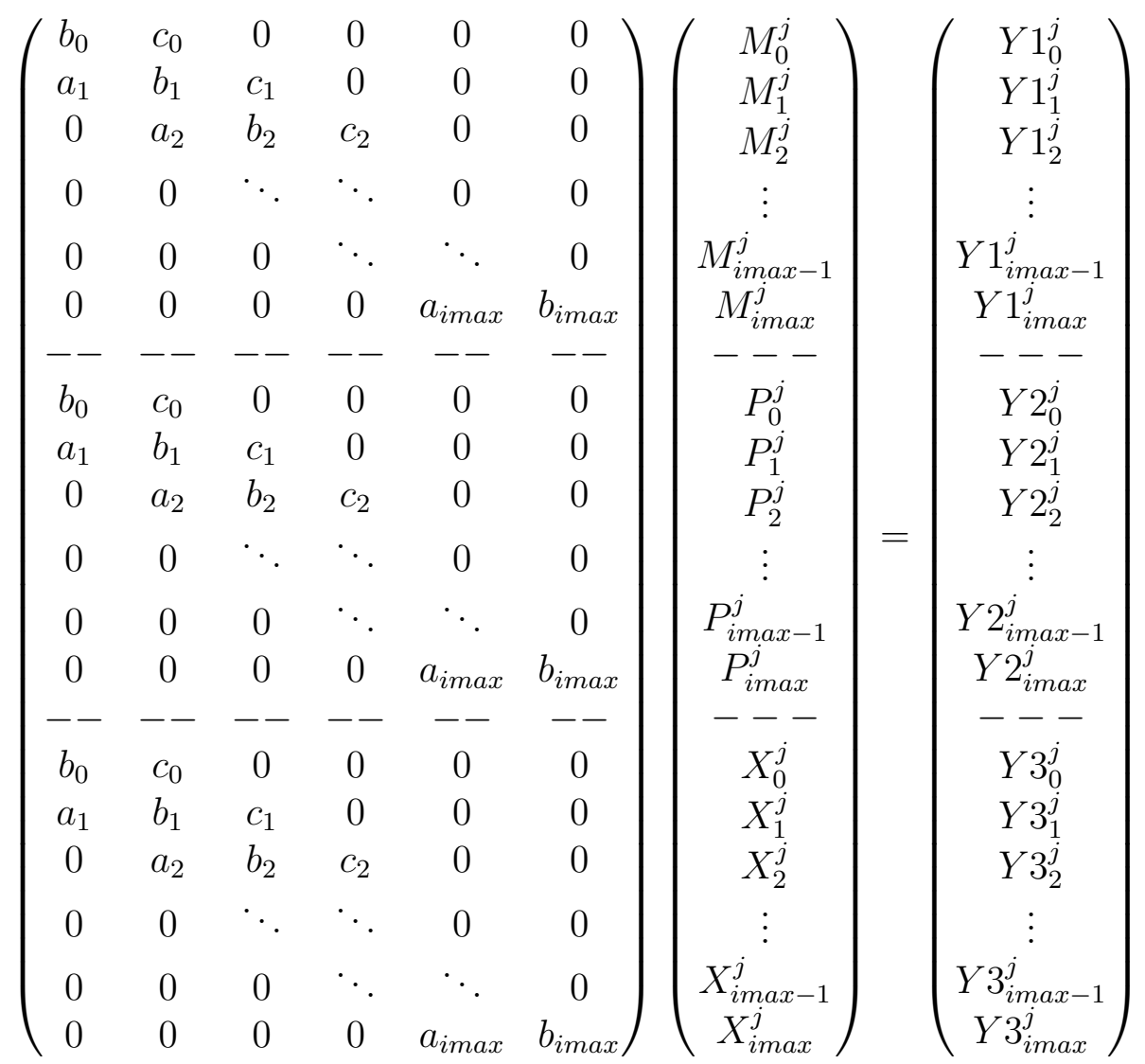

where

$$
\begin{gathered}
Y 1_{i}^{j}=\left(\frac{D_{M}}{2(\Delta x)^{2}}+\frac{v}{4 \Delta x}\right) M_{i-1}^{j+1}+\left(-\frac{A}{\Delta t}+\frac{D_{M}}{(\Delta x)^{2}}\right) M_{i}^{j+1}+\left(\frac{D_{M}}{2(\Delta x)^{2}}-\frac{v}{4 \Delta x}\right) M_{i+1}^{j+1}, \\
Y 2_{i}^{j}=\left(\frac{D_{P}}{2(\Delta x)^{2}}+\frac{v}{4 \Delta x}\right) P_{i-1}^{j+1}+\left(-\frac{A}{\Delta t}+\frac{D_{P}}{(\Delta x)^{2}}\right) P_{i}^{j+1}+\left(\frac{D_{P}}{2(\Delta x)^{2}}-\frac{v}{4 \Delta x}\right) P_{i+1}^{j+1},
\end{gathered}
$$




$$
Y 3_{i}^{j}=\left(\frac{D_{X}}{2(\Delta x)^{2}}+\frac{v}{4 \Delta x}\right) X_{i-1}^{j+1}+\left(-\frac{A}{\Delta t}+\frac{D_{X}}{(\Delta x)^{2}}\right) X_{i}^{j+1}+\left(\frac{D_{X}}{2(\Delta x)^{2}}-\frac{v}{4 \Delta x}\right) X_{i+1}^{j+1} .
$$

Equation (18) with the given initial and boundary conditions in equation (7) and equation (8) was solved using Mathematica routine NDSolve with Crank-Nicolson method as earlier discussed.

\section{$5 \quad$ Numerical Results}

The results are depicted in Figures 7-15. Figure 7 and Figure 8 showed the 3D and contour plot of the solution of PSB along the pond $(x)$ and time $(t)$. Figure 9 and Figure 10 describe the 3D and contour plot of pollutant (COD). Meanwhile, Figure 11 and Figure 12 present the 3D and contour plot of DO. Lastly, the comparison between the simulated Model and the experimental data at CP2 for all three state variables was shown in Figures 13-15 for PSB, COD and DO, respectively.

Table 6: Values of Calibrated Constants and Values Specified in Literature

\begin{tabular}{|c|c|c|l|l|}
\hline Symbol & Model Calibration & Value & Unit & Source \\
\hline$\mu_{b}$ & 0.6 & $2-10$ & day $^{-1}$ & Tchobanoglous and \\
$k_{L}$ & 4 & 2.67 & $\mathrm{~m}^{2}$ day $^{-1}$ & Burton [14] \\
\hline$D_{X}$ & 50 & 45 & $\mathrm{~m}^{2}$ day $^{-1}$ & \\
$D_{M}$ & 50 & 45 & $\mathrm{~m}^{2}$ day $^{-1}$ & Beran and Kargi [9] \\
$D_{P}$ & 50 & 45 & $\mathrm{~m}^{2}$ day $^{-1}$ & \\
\hline$k_{m}$ & 0.00017 & $0-0.1$ & $\mathrm{~g} \mathrm{~m}^{-3}$ & Ahmed and Mayo [15] \\
\hline
\end{tabular}

The simulated model demonstrated a result from all state variables supporting the experimental data given at CP2. As can be seen, the amount of DO in the pond increased as time increases. The variation of PSB in the pond showed that the concentration of PSB has continuously increased until the end of treatment period. Lastly, an increase in COD concentration was observed throughout the treatment period. This was due to the increased amount of COD that goes into the oxidation pond as time increases, which was displayed from the data provided by J-Biotech.

\section{Conclusion}

In summary, this study has proposed a mathematical model for oxidation pond treatment system. The PDEs model comprising advection-diffusion-reaction equations for transporting pollutants. This mathematical model was considered as the best model in terms of complexity along with a good result compared to experimental data. 


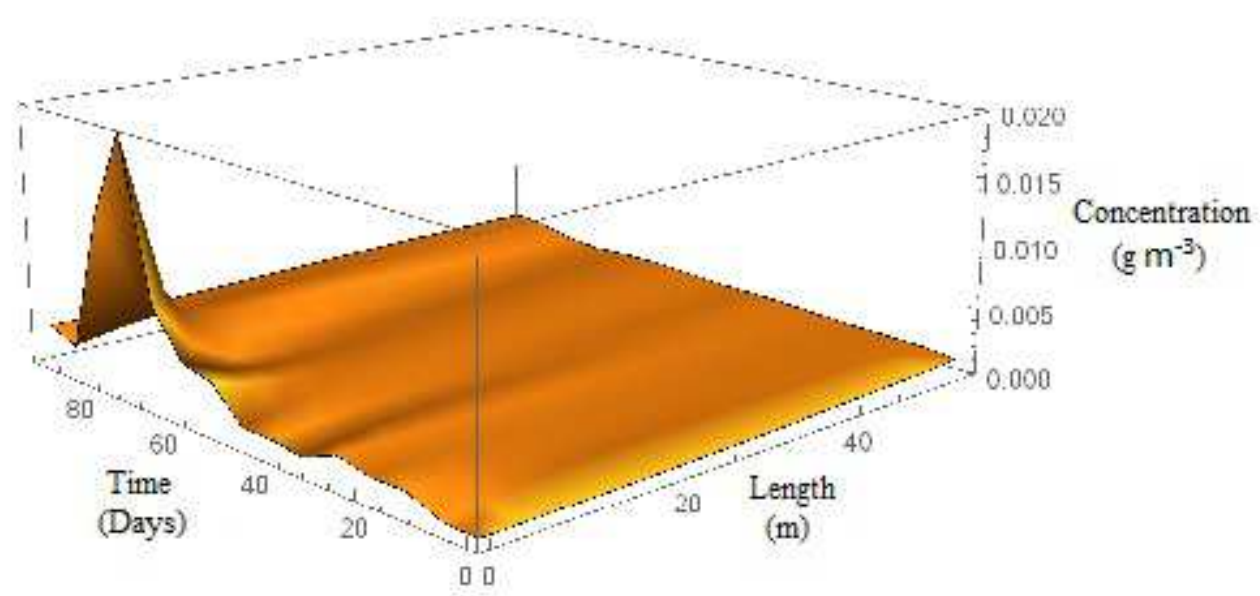

Figure 7: 3D Graph of PSB Based on the Mathematical Model

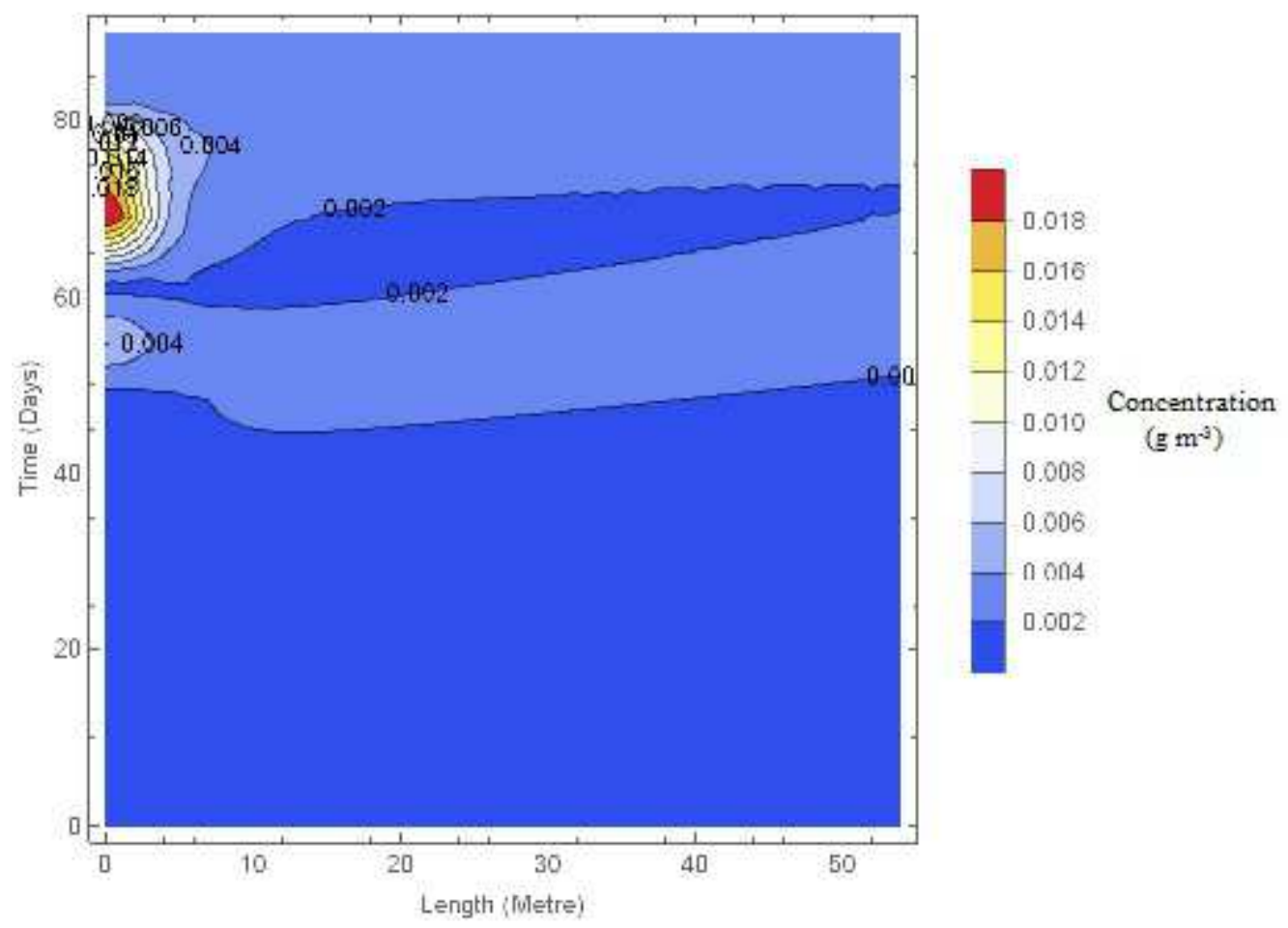

Figure 8: Contour Plot of PSB Based on the Mathematical Model 


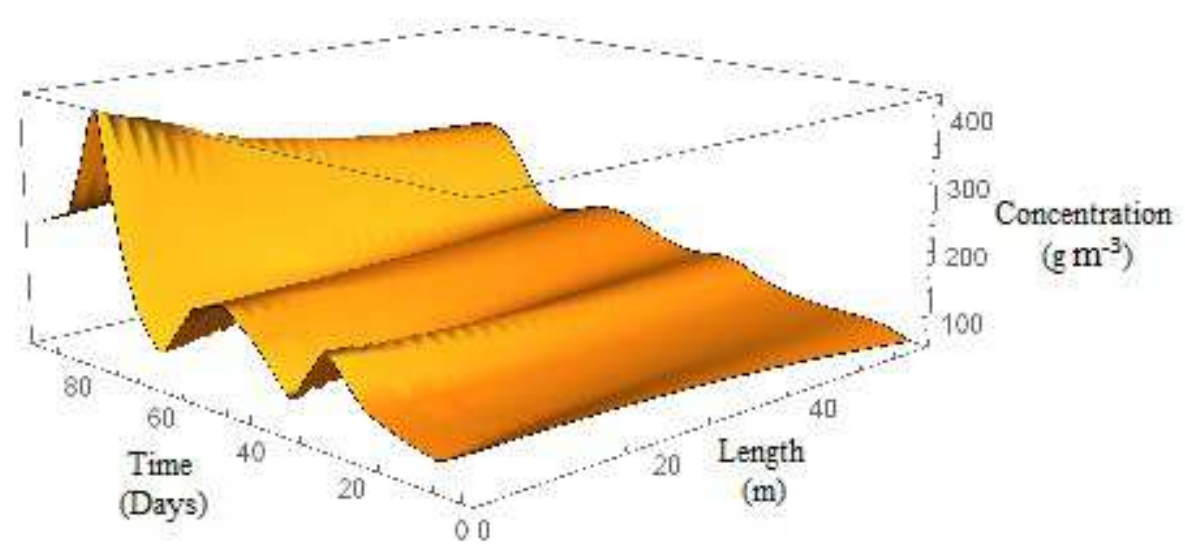

Figure 9: 3D Graph of COD Based on the Mathematical Model

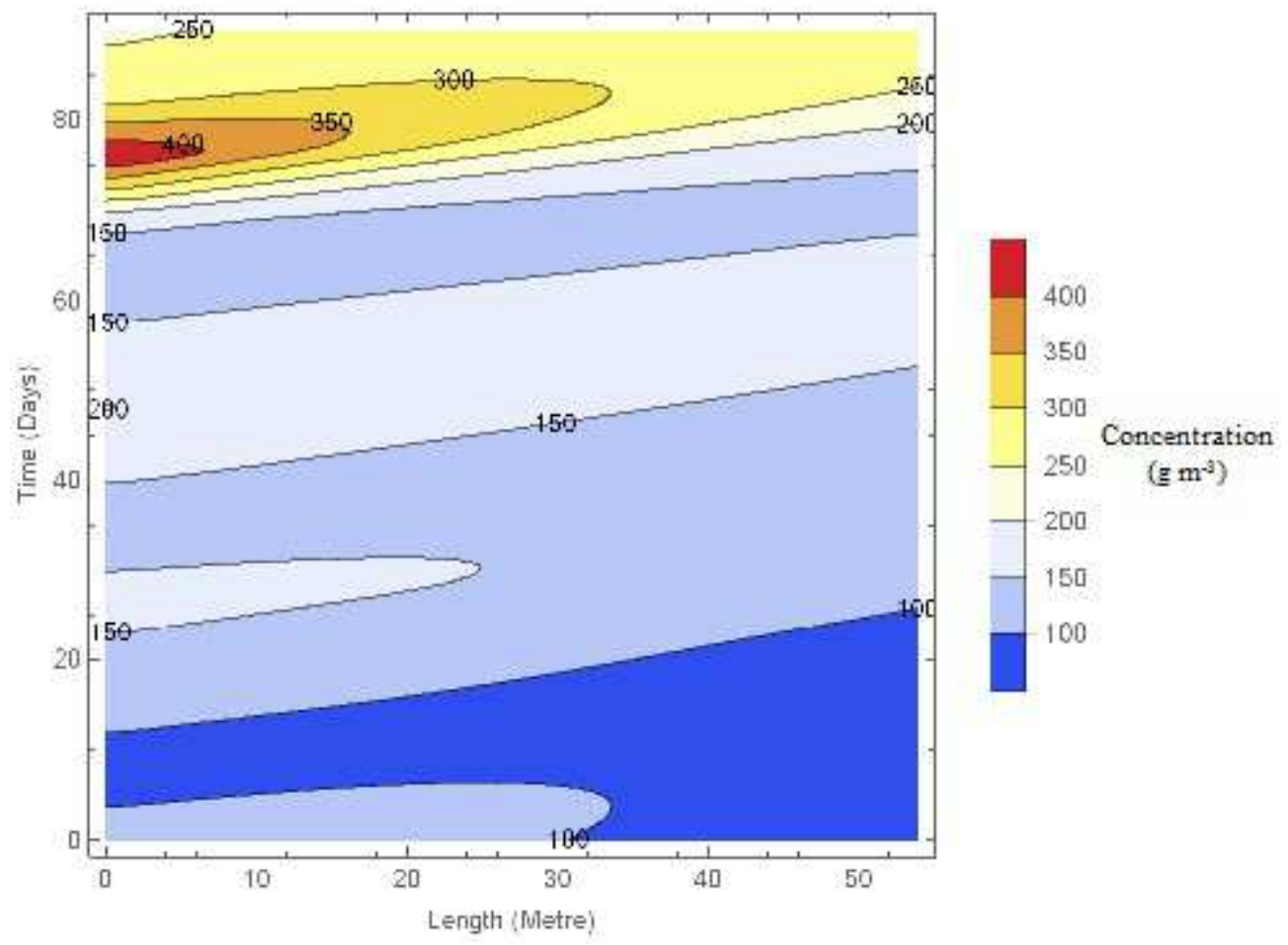

Figure 10: Contour Plot of COD Based on the Mathematical Model 


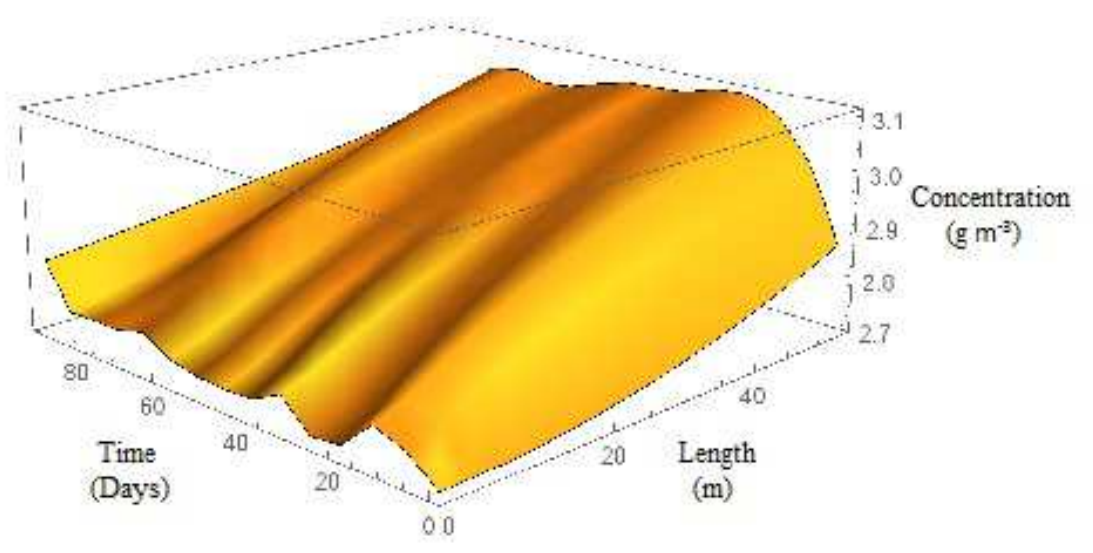

Figure 11: 3D Graph of DO Based on the Mathematical Model

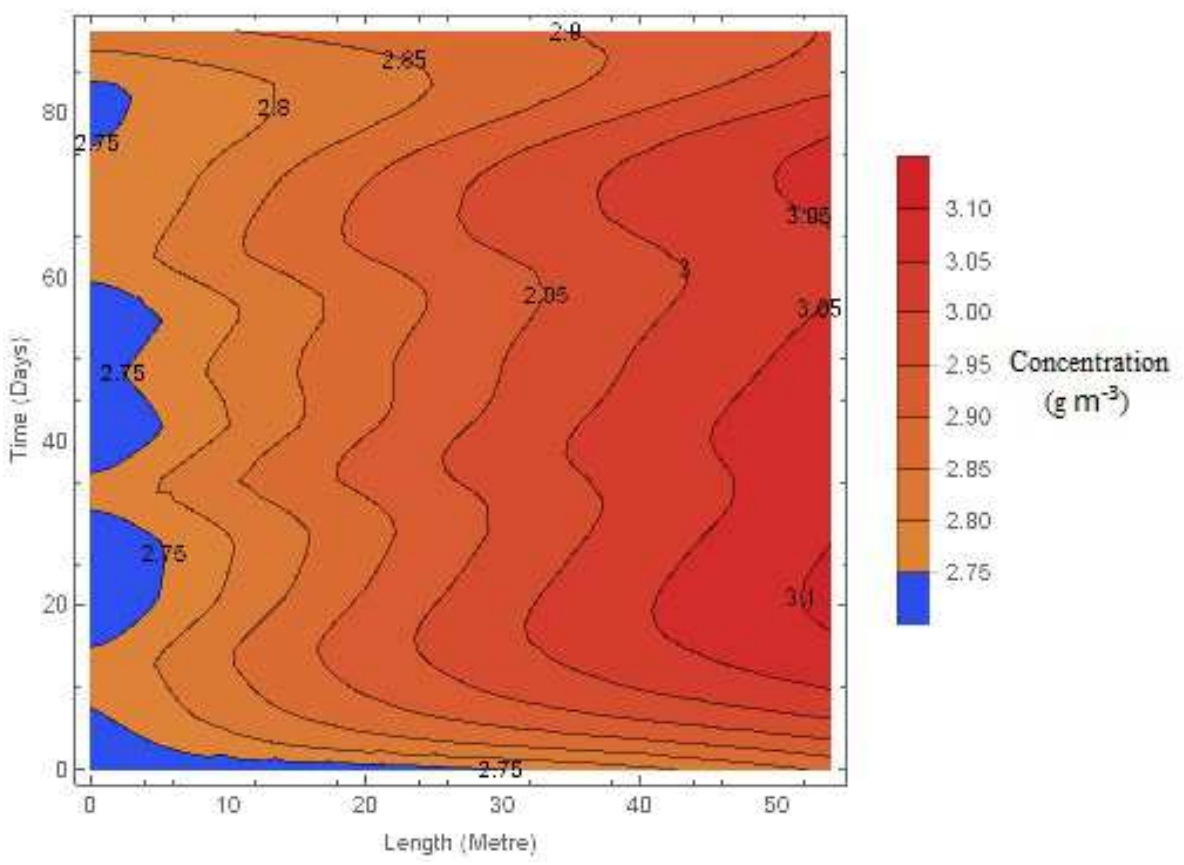

Figure 12: Contour Plot of DO Based on the Mathematical Model 


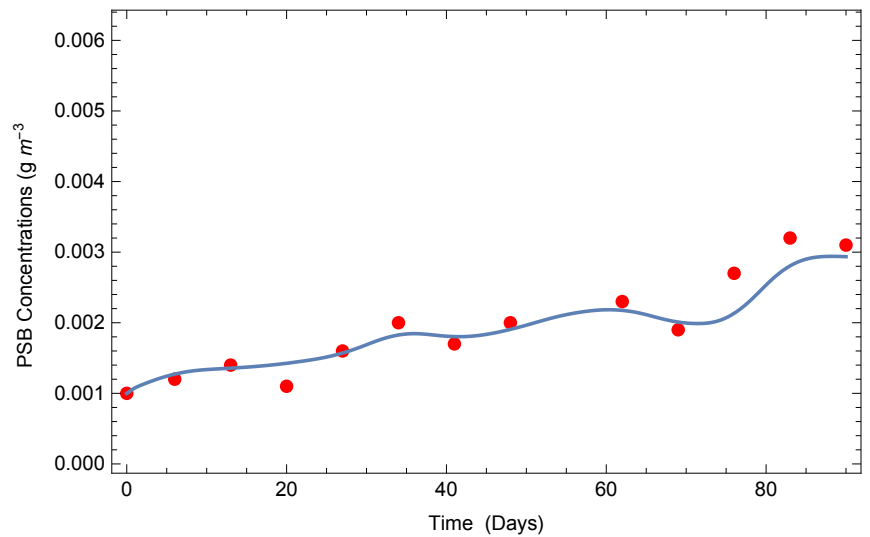

Figure 13: Graphical Comparison between Experimental Data and Simulated Model for PSB (The blue curve represents the numerical results and red dots are the experimental data $\left(\mathrm{R}^{2}=\right.$ $0.90)$ )

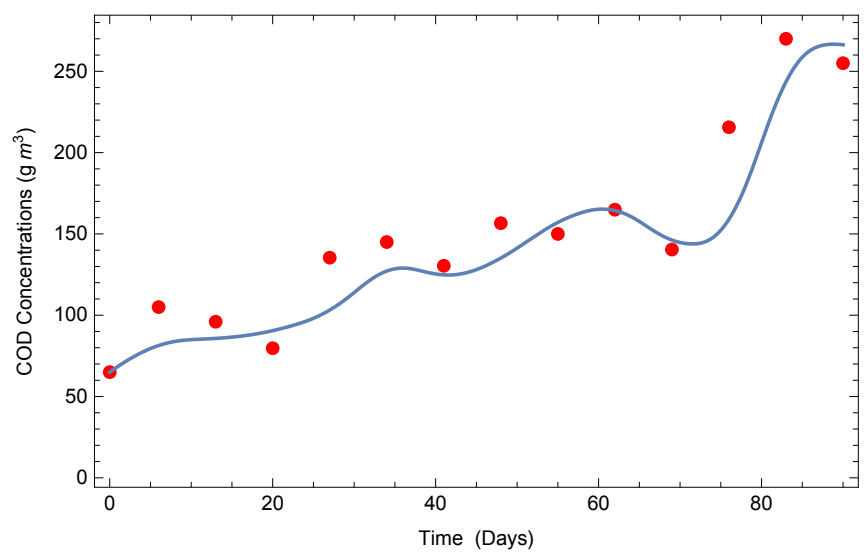

Figure 14: Graphical Comparison between Experimental Data and Simulated Model for COD (The blue curve represents the numerical results and red dots are the experimental data $\left(\mathrm{R}^{2}=\right.$ $0.86)$ )

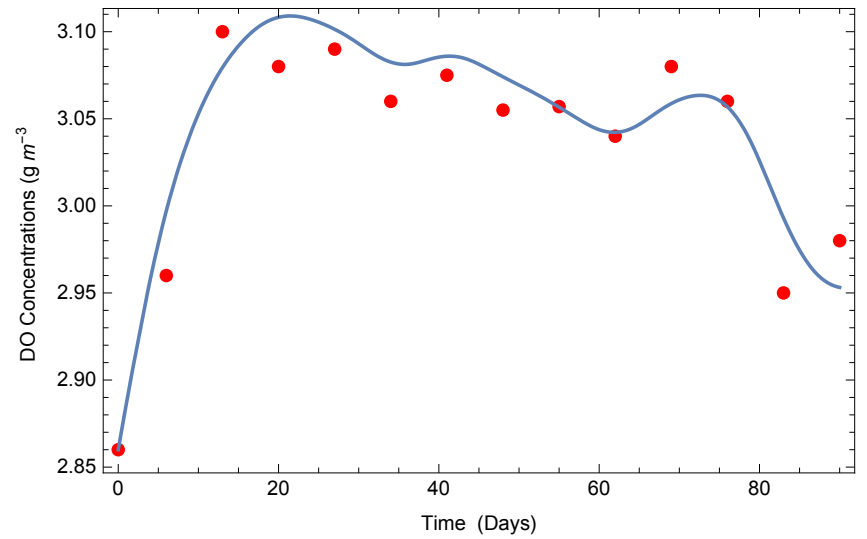

Figure 15: Graphical Comparison between Experimental Data and Simulated Model for DO (The blue curve represents the numerical results and red dots are the experimental data $\left(\mathrm{R}^{2}=\right.$ $0.92)$ ) 


\section{Acknowledgment}

We thank Assoc. Prof. Dr. Sharidan Shafie and Assoc. Prof. Dr. Mukhiddin Muminov for their review, careful reading and detailed comments on this paper. We also thank the Universiti Teknologi Malaysia (UTM), Ministry of High Education (MOHE) for the financial support through the research grant with vote no. R.J130000.7809.4F637 and STEM Grant with vote no. A. J091002.5600.07397.

\section{References}

[1] Abdel-Shafy, H. I. and Salem, M. A. Efficiency of oxidation ponds for wastewater treatment in Egypt. In: Wastewater reuse-risk assessment, decision-making and environmental security. Springer. 2007. 175-184.

[2] Davies, P. S. The biological basis of wastewater treatment. Strathkelvin Instruments Ltd. 2005. 3-11.

[3] Ockendon, J. R., Wake, G., Teo, K. L., Loxtan, R., Araujo, A., Widodo, B., Murid, A. H. M., Hoe, Y. S., Banitalebi, A., Johar, F. and Siam, F. M. Mathematical modeling and optimization for biological-based treatment of Taman Timor Oxidation Pond, Johor. Malaysian $2^{\text {nd }}$ Mathematics in Industry Study Group (MISG 2014). March 17-21, 2014. Universiti Teknologi Malaysia, Johor Bahru, Malaysia. 2014. 1-37.

[4] Beck, M. B. and Young, P. C. A dynamic model for DO-BOD relationships in a non-tidal stream. Water Research. 1975. 9(9): 769-776.

[5] Pimpunchat, B., Sweatman, W. L., Wake, G. C., Triampo, W. and Parshotam, A. A mathematical model for pollution in a river and its remediation by aeration. Applied Mathematics Letters. 2009. 22: 304-308.

[6] Sebenik Paul Gregory. Relationships of Dissolved Oxygen and Biochemical Oxygen Demand in Sewage Effluent Releases. Ph.D. Thesis. The University of Arizona, Tucson, Arizona. 1975.

[7] Abdulkareem, A. Modeling of microbial growth in a wastewater treatment plant: A case study of textile industry in Kaduna, Nigeria. AU Journal of Technology. 2004. 8: 45-54.

[8] Bhutiani, R. and Khanna, D. Ecological study of river Suswa: Modeling DO and BOD. Environmental Monitoring and Assessment. 2007. 125: 183-195.

[9] Beran, B. and Kargi, F. A dynamic mathematical model for wastewater stabilization ponds. Ecological Modelling. 2005. 181: 39-57.

[10] Morley, D. A. Mathematical Modelling in Water and Wastewater Treatment. London: Applied Science Publishers. 1979.

[11] Seviour, R. J. and Nielsen, P. H. Microbial Ecology of Activated Sludge. New York: IWA publishing. 2010.

[12] Edelstein-Keshet, L. Mathematical Models in Biology. Philadelphia: SIAM. 1988.

[13] Howison, S. Practical Applied Mathematics: Modelling, Analysis, Approximation. United Kingdom: Cambridge University Press. 2005. 
[14] Tchobanoglous, G. and Burton, F. Wastewater Engineering: Treatment, Disposal, and Reuse (3rd. ed.). New York: McGraw-Hill. 1991.

[15] Ahmed, M. G. and Mayo, A. W. Modeling of mortality rate of heterotrophic bacteria due to chromium in waste stabilization pond. Journal of Science and Technology. 2013. 14(2). 